Preprints are preliminary reports that have not undergone peer review.

They should not be considered conclusive, used to inform clinical practice,

or referenced by the media as validated information.

\title{
Statistics and Formation Mechanism Analysis on the Basin-Range Patterns of Granite Bodies in Hunan Province, China
}

\author{
Runchu Wei ( $\nabla$ weirunchu@163.com ) \\ 7038-1628 \\ Chenmo Rao \\ Changsha University of Science and Technology \\ Zhendong Cao \\ Bureau of geology and mineral exploration and development of Guizhou Province \\ Hui Zhou \\ Hunan hydrology and water resources survey bureau \\ Yi Zhu \\ Loudi hydrology and water resources survey bureau of Hunan Province \\ Peng Chen \\ Loudi hydrology and water resources survey bureau of Hunan Province \\ Qi Ouyang \\ Changsha University of Science and Technology
}

Changsha University of Science and Technology - Yuntang Campus: Changsha University of Science and Technology https://orcid.org/0000-0001-

\section{Research Article}

Keywords: granite, basin-range framework, tectonism, anti-weathering, basin material flux

Posted Date: July 30th, 2021

DOI: https://doi.org/10.21203/rs.3.rs-533531/v1

License: (c) (1) This work is licensed under a Creative Commons Attribution 4.0 International License. Read Full License 


\section{Abstract}

This paper presents the results of statistical analysis on the basin-range relations between the granite rock bodies and surrounding rocks in Hunan Province of China. Among the 44 granitoids in Hunan Province, 28 are basins, 14 are ranges, and only 2 cannot be directly classified. The basin-range properties of granite bodies are closely related to the lithology of surrounding rocks. Among the 28 granite basins, 24 are surrounded by slate, 3 by sandstone, and only 1 by glutenite, while 11 of 14 ranges are surrounded by carbonate rocks. From the perspective of endodynamic process, tectonic movements played an important role in the evolution of the terrain in the granite areas. Firstly, tectonism shaped the large-scale tectonic framework which deter-mined the distribution of some granite mountains in Hunan Province. In addition, tectonic compression or extension formed some granite compressional uplifts or horsts, which present as ranges now. From the perspective of differential weathering, the difference of resistance to weathering between granite and their surrounding rocks is an essential factor for the development of granite basin or range. When their surrounding rocks are carbonate rocks, the granite areas mostly present as ranges for the high solubility of carbonate minerals. When their surrounding rocks are slate rocks, the granite areas are mostly basins for their lower resistance to weathering than slate rocks determined by their more unstable minerals to weathering and more conductive soils to rainfall infiltration.

\section{Introduction}

Basin and range are the basic geomorphic forms of the earth, which are widely distributed on the land and essential parts of the gorgeous submarine topography. Basin and range evolution mechanisms have always been the forefront research topic of geology, geography, geophysics, and other geosciences that involve a wide range of fields such as tectonics (Li et al. 2013), magmatism (Wang et al. 2003), geomagnetic evolution (Sun et al. 2019), and rock weathering (Cui et al. 2019). Basin-range pattern has an obvious scale effect. The formation mechanisms of basin-range patterns within different spatial scales are often quite different. Large-scale basin-mountain systems are usually controlled by global-scale tectonic movements, among which Tibetan-Ganges Plateau-Basin system is a typical example (Powell et al. 1973; Zhou et al. 2005). On the medium scale, basins are mostly the results of local tectonic subsidence. For example, the Dongting Lake Basin, which is located in south-central China, was formed after multistage intraplate tectonic movements (Pi et al. 2001). From a small-scale point of view, the formation of basins and ranges is related to both tectonic movements and the differences of the adjacent rocks' resistance to weathering (Cui et al. 2007).

China is one of the countries with the most extensive distribution of granite masses in the world, with a total area of $909,000 \mathrm{~km}^{2}$, of which about $60 \%$ are distributed in southern China. Granites with different ages, genesis, and lithology types different geomorphic forms in different climatic zones, altitudes, and different areas of exogenous force.

Based on morphological laws, some scholars have systematically summarized the main geomorphic features and types of granite (Twidale 1982; Twidale et al. 2005). They have divided the main granite landforms into boulders, inselbergs, slopes, topology, and plains, and considered boulders as the primary geomorphic manifestation of granite. In China, as early as the 1960s, Zeng (Zeng. 1960) divided the granite landforms into five types according to China's granite characteristics, which are alpine granite terrain, tropical granite terrain, dry area granite terrain, egg terrain, and gully terrain respectively. Later, Cui et al. (2007) divided the granite landform into four categories from the perspective of weathering and erosion in the formation process of granite landforms. Geomorphic system results from the interaction of internal and external forces on the surface (Yang et al. 2012), and the landform in granite area is also affected by three main factors, namely lithology, tectonic movement and climate.

Up until now, scholars have done many researches on the geomorphology and formation mechanisms of granite areas and have obtained numerous results. Among those studies, most are carried out from the perspective of morphology, mainly focusing on micro-topography, while little attention is paid to the macro scale basin-range characteristics of granite. For a single rock mass, if there is no obvious influence of tectonic uplift or subsidence, the basin-range pattern is mainly determined by the difference of resistance to weathering between the rock mass and its surrounding rock. Antiweathering characteristics of different lithologies often vary with diverse climate backgrounds. Under certain circumstances, the characteristics may have completely opposite results. (Cui et al. 2007).

Granite bodies are widely distributed in South China, with variable surrounding rocks and structural characteristics that cause complex basin-range patterns. Understandings on the basin-range formation mechanisms vary. (Li 2008).

In order to deepen the understanding of basin-range formation mechanisms of granite bodies, statistics on the basin-range patterns of the 44 granite bodies in the Hunan Province, where the spatial distributions of granite are relatively simple, were carried out based on the digital elevation data (DEM) and the previous geological survey results. Then, the mechanism of spatial basin-range pattern was revealed based on the combined analysis of tectonic movement and mineral composition.

\section{Materials And Methods}

\subsection{Introduction to Granite in Hunan Province}

The total outcropping area of Granitoids in Hunan Province is about 17,000 km², which formed in different tectonic periods, including Wuling Period (Early Neoproterozoic), Caledonian Period (from Early Silurian to Middle Silurian), Indosinian Period (from Middle Triassic to Late Triassic), and 
Yanshanian Period (from Middle Jurassic to Late Jurassic). Among them, the second stage of Caledonian (Early Silurian), Indosinian Period (Middle Triassic) and Early Yanshan Period (Middle Jurassic) are the three main peak periods of granite magma intrusion in this area (Fig. 1).

The granites of Wuling Period were found only in Liuyang City, northeast Hunan Province. They were controlled by an EW geological structure of this period and invaded into the strata of Lengjiaxi Group. In Late Silurian Period, the main episode of Caledonian tectonism began, mainly represented by intracontinental orogeny. In Late Caledonian Period, large-scale granitic magmatism occurred in the regions east of Chengbu-Xinhua Fault in the postcollisional environment of weakening compression and stress relaxation (Bai et al. 2006). The rock masses are mainly distributed in some areas surrounding the Late Paleozoic basin in Central Hunan, including Wangyang-Zhuguang Mountain, Penggongmiao, Banshanpu, Baimashan, Miaoershan, Yuechengling, and Jiuweishan.

The Caledonian granite bodies exhibit a widespread and large distribution throughout the study area, most of which were shaped in the second stage of Caledonian Period, and some of which formed compound rock bodies with later intrusive rocks. The Caledonian granites are mainly biotite monzogranite, granodiorite, and syenite granite, of which Baimashan Body, WangyangShan Body, and MiaoerShan Body are the representative granite bodies.

The main episode of Indosinian Movement began in Late Middle Triassic Period. This tectonic movement produced many NNE folds with the help of NWW compression stress (Bai et al. 2005; Bai et al. 2007). At the beginning of Indosinian movement, some granite bodies were formed in the process of tectonic collision, mainly distributed in Guandimiao, Baimashan and Sheshanshan. In Late Triassic Period, the Late Indosinian rocks were formed in the post-collisional environment of stress relaxation, including the Yangmingshan, Wawutang, Guandimiao, Taojiang, and Baimashan rock bodies.

From Mid Jurassic Period to Late Jurassic Period, Yanshanian Movement produced the largest area of granite bodies in the southeast of the Province (Shu. 2012). The late Yanshanian granitic magma activity is the end of magmatism in the Province, and the outcropping area is very small.

\subsection{Research Framework and Data}

In this paper, the statistics for the basin-range pattern of the 44 granite bodies were carried out firstly based on the digital elevation model (Aster GDEM $30 \mathrm{~m}$ resolution DEM). Then, the basin-range mechanisms were analyzed from two aspects of tectonic action and weathering resistance. Finally, the erosion levels of basins with different dominant lithology were compared based on the material flux analysis.

In order to support the above study, this research got 394 granite samples and 98 slate samples from all over Hunan Province and sent them to Hunan Province Geological Testing Institute for mineral analysis.

In addition, sediment daily monitoring data from 1961 to 2019 of 10 hydrological stations with different geological background and water monthly quality monitoring data from 2014 to 2018 of 8 stations in Xiangjiang River Basin were collected to carry out material flux analysis (Fig. 1). Both the sediment data and water quality data were the results of the regular monitoring of hydrological stations of Hunan Hydrology and Water Resources Survey Bureau.

In 1987, Zhang et al carried out a large-scale investigation of river water chemistry in the Xiangjiang River Basin of Hunan Province (Zhang et al. 1987), which gained a lot of high-quality water chemistry data. In this paper, a small part of their work is cited to support the material flux analysis.

\section{Results}

\subsection{Analysis of Basin-range Relationship between Granite Mass and Surrounding Rock in Hunan Province}

Based on the Aster GDEM data, the topographic map of Hunan Province was drawn and the granite distribution map was nested to obtain the topographic and granite mosaic map of Hunan Province (Fig. 2). Based on Fig. 2, the basin or range properties of all granite bodies were identified. Table 1 shows the basin-range type of the main granite bodies. 
Table 1

Basin-range framework and main surrounding rocks of Granite in Hunan Province

\begin{tabular}{|c|c|c|c|c|c|c|c|c|}
\hline \multirow[t]{2}{*}{ Number } & \multirow{2}{*}{$\begin{array}{l}\text { Rock Body } \\
\text { (Group) }\end{array}$} & \multirow[t]{2}{*}{ Type } & \multicolumn{2}{|l|}{ Granite } & \multicolumn{2}{|c|}{ Surrounding rock》 } & \multicolumn{2}{|c|}{ Surrounding rock》 } \\
\hline & & & Category & $\begin{array}{l}\text { Geological } \\
\text { Period }\end{array}$ & Lithology & $\begin{array}{l}\text { Geological } \\
\text { Period }\end{array}$ & Lithology & $\begin{array}{l}\text { Geological } \\
\text { Period }\end{array}$ \\
\hline 1 & Taohuashan & Range & Monzogranite & Jurassic & Clay & Quaternary & Slate & Neoproterozoic \\
\hline 2 & Mubushan & Basin & Monzogranite & Jurassic & Slate & Neoproterozoic & Sandstone & Neoproterozoic \\
\hline 3 & Wangxiang & Basin & Monzogranite & Jurassic & Slate & Neoproterozoic & Sandstone & Neoproterozoic \\
\hline 4 & Jingjin & Basin & Monzogranite & Jurassic & Slate & Neoproterozoic & & \\
\hline 5 & Dingziwan & Basin & Monzogranite & Jurassic & Slate & Neoproterozoic & Sandy clay & Quaternary \\
\hline 6 & Lianyunshan & Basin & Monzogranite & Jurassic & Slate & Neoproterozoic & Sandstone & Cretaceous \\
\hline 7 & Changsanbei & Basin & Monzogranite & Neoproterozoic & $\begin{array}{l}\text { Sandy } \\
\text { slate }\end{array}$ & Neoproterozoic & Sandstone & Neoproterozoic \\
\hline 8 & Jiaoxi & Basin & Monzogranite & Jurassic & Slate & Neoproterozoic & mudstone & Devonian \\
\hline 9 & Taojiang & Basin & Monzogranite & Triassic & $\begin{array}{l}\text { Sandy } \\
\text { slate }\end{array}$ & Neoproterozoic & $\begin{array}{l}\text { Calcareous } \\
\text { slate }\end{array}$ & Neoproterozoic \\
\hline 10 & Yanbaqiao & Basin & Monzogranite & Triassic & $\begin{array}{l}\text { Sandy } \\
\text { slate }\end{array}$ & Neoproterozoic & & \\
\hline 11 & Sanchuangpu & Basin & Monzogranite & Triassic & $\begin{array}{l}\text { Sandy } \\
\text { slate }\end{array}$ & Neoproterozoic & Sandy clay & Quaternary \\
\hline 12 & Tieshanpu & Basin & Monzogranite & Silurian & $\begin{array}{l}\text { Sandy } \\
\text { slate }\end{array}$ & Neoproterozoic & & \\
\hline 13 & Weishan & Basin & Monzogranite & Triassic & Slate & Neoproterozoic & Sand shale & Devonian \\
\hline 14 & Xiema & Basin & Monzogranite & Triassic & Slate & Neoproterozoic & Mudstone & Paleogene \\
\hline 15 & Ziyunshan & Basin & Monzogranite & $\begin{array}{l}\text { Triassic, } \\
\text { Silurian }\end{array}$ & Slate & Neoproterozoic & Mudstone & Paleogene \\
\hline 16 & Nanyue & Range & Monzogranite & Triassic & Glutenite & Cretaceous & Sandy slate & Neoproterozoic \\
\hline 17 & Wuji & Basin & Granodiorite & Silurian & $\begin{array}{l}\text { Sandy } \\
\text { slate }\end{array}$ & Neoproterozoic & Glutenite & Devonian \\
\hline 18 & Yajiangqiao & Basin & Monzogranite & Triassic & Slate & Neoproterozoic & Glutenite & Cretaceous \\
\hline 19 & Guandimiao & Basin & Monzogranite & Triassic & Slate & Ordovician & Sandstone & Ordovician \\
\hline 20 & Denghuxian & Basin & Monzogranite & $\begin{array}{l}\text { Jurassic, } \\
\text { Triassic }\end{array}$ & Sandstone & Cretaceous & Sand shale & Devonian \\
\hline 21 & Xitian & Basin & Monzogranite & Triassic & Sandstone & Cretaceous & Sand shale & Devonian \\
\hline 22 & Wufengxian & Range & Granodiorite & Triassic & Carbonate & Devonian & Carbonate & Permian \\
\hline 23 & $\begin{array}{l}\text { North } \\
\text { Zhuguangshan }\end{array}$ & Unidentifiable & $\begin{array}{l}\text { Monzogranite, } \\
\text { Granodiorite }\end{array}$ & $\begin{array}{l}\text { Silurian, } \\
\text { Triassic, } \\
\text { Jurassic }\end{array}$ & Slate & Neoproterozoic & $\begin{array}{l}\text { Argillaceous } \\
\text { limestone }\end{array}$ & Cambrian \\
\hline 24 & Dongfeng & Basin & Monzogranite & Silurian & Glutenite & Ordovician & Sand shale & Devonian \\
\hline 25 & Penggongmiao & Basin & Monzogranite & Silurian & Slate & Cambrian & carbonate & Devonian \\
\hline 26 & Dayishan & Range & Monzogranite & Jurassic & Carbonate & Carboniferous & $\begin{array}{l}\text { Argillaceous } \\
\text { limestone }\end{array}$ & Devonian \\
\hline 27 & Tashan & Range & Monzogranite & Triassic & Carbonate & Carboniferous & Sandy slate & Ordovician \\
\hline 28 & Tuao & Basin & Monzogranite & Triassic & Sandstone & Ordovician & Glutenite & Cambrian \\
\hline 29 & Yangmingshan & Basin & Monzogranite & Triassic & $\begin{array}{l}\text { Sandy } \\
\text { slate }\end{array}$ & Ordovician & Glutenite & Devonian \\
\hline 30 & Qitianling & Range & Monzogranite & Jurassic & Carbonate & Permian & Carbonate & Carboniferous \\
\hline 31 & $\begin{array}{l}\text { South } \\
\text { Zhuguangshan }\end{array}$ & Basin & Monzogranite & Jurassic & Slate & Cambrian & Sandy slate & Neoproterozoic \\
\hline 32 & Dadongshan & Range & Monzogranite & Jurassic & Carbonate & Devonian & Carbonate & Carboniferous \\
\hline
\end{tabular}




\begin{tabular}{|c|c|c|c|c|c|c|c|c|}
\hline \multirow[t]{2}{*}{ Number } & \multirow{2}{*}{$\begin{array}{l}\text { Rock Body } \\
\text { (Group) }\end{array}$} & \multirow[t]{2}{*}{ Type } & \multicolumn{2}{|l|}{ Granite } & \multicolumn{2}{|c|}{ Surrounding rock》 } & \multicolumn{2}{|c|}{ Surrounding rock》 } \\
\hline & & & Category & $\begin{array}{l}\text { Geological } \\
\text { Period }\end{array}$ & Lithology & $\begin{array}{l}\text { Geological } \\
\text { Period }\end{array}$ & Lithology & $\begin{array}{l}\text { Geological } \\
\text { Period }\end{array}$ \\
\hline 33 & Xishan & Range & Monzogranite & Jurassic & Carbonate & Devonian & Slate & Cambrian \\
\hline 34 & Jingjiling & Range & Monzogranite & $\begin{array}{l}\text { Jurassic, } \\
\text { Triassic }\end{array}$ & Carbonate & Devonian & Sandstone & Cambrian \\
\hline 35 & Xuehuading & Range & Monzogranite & Jurassic & Carbonate & Devonian & Sandstone & Cambrian \\
\hline 36 & Guposhan & Range & Monzogranite & Jurassic & Carbonate & Devonian & Sandstone & Cambrian \\
\hline 37 & Yuechenling & Range & Monzogranite & Triassic & Carbonate & Devonian & Sandy slate & Ordovician \\
\hline 38 & Miaoershan & Basin & Monzogranite & $\begin{array}{l}\text { Jurassic, } \\
\text { Silurian }\end{array}$ & $\begin{array}{l}\text { Sandy } \\
\text { slate }\end{array}$ & $\begin{array}{l}\text { Nanhua } \\
\text { system }\end{array}$ & carbonate & Devonian \\
\hline 39 & Wutuan & Range & Monzogranite & Triassic & $\begin{array}{l}\text { Sandy } \\
\text { slate }\end{array}$ & Neoproterozoic & Sandy slate & $\begin{array}{l}\text { Nanhua } \\
\text { system }\end{array}$ \\
\hline 40 & Wawutang & Basin & Monzogranite & Triassic & Slate & Ordovician & Slate & Silurian \\
\hline 41 & Chongyangpin & Basin & Monzogranite & Triassic & Slate & Ordovician & Slate & Cambrian \\
\hline 42 & Baimassi & Unidentifiable & Monzogranite & $\begin{array}{l}\text { Silurian, } \\
\text { Triassic, } \\
\text { Jurassic }\end{array}$ & Slate & Neoproterozoic & Sandy slate & Ordovician \\
\hline 43 & Tianmashan & Range & Monzogranite & Triassic & Carbonate & Devonian & Slate & Cambrian \\
\hline 44 & Chenshan & Basin & Monzogranite & Triassic & $\begin{array}{l}\text { Sandy } \\
\text { slate }\end{array}$ & Neoproterozoic & Sandstone & Cambrian \\
\hline
\end{tabular}

Table 1 shows that, among the 44 granite bodies (including granodiorite) in Hunan Province, 28 are granite basins, 14 are ranges, and only 2 granite body masses, including North Zhuguangshan and Baimasi, cannot be directly classified. According to the statistical results of surrounding rocks, the basin-range properties of granite are closely related to the lithology of surrounding rocks. Among the 28 granite basins, 24 are surrounded by slate, 3 by sandstone, and 1 by glutenite, while 11 of 14 ranges are surrounded by carbonate rocks.

\subsection{Analysis of Basin-range Characteristics in Composite Rock Masses}

As mentioned above, the basin-range characteristics of North Zhuguangshan rock mass and Baimasi rock mass are unidentifiable. In fact, the North Zhuguangshan and Baimasi rock masses are both typical composite rock masses that share basin and range inlay characteristics.

The Northern Zhuguangshan rock mass is located in Luoxiao Mountain in the southwest of Hunan Province, which was formed from Early Silurian Period to Late Jurassic Periods (Fig. 3). The Baimasi rock mass is located in Xuefeng Mountain in the middle of Hunan Province, that was formed from Middle Silurian Perion to Late Jurassic Period (Fig. 4) (Liu et al. 2016).

According to the basin-range relationships among different rocks formed in different geologic periods, the two rock masses both show the same characteristics that, younger rocks are more inclined to develop into ranges than their adjacent older rock masses. Specifically, all the Silurian rock bodies of the North Zhuguangshan rock masses are basins, while the adjacent Jurassic and Triassic rock bodies are ranges (Fig. 3), and all the Jurassic rock bodies of the Baimasi rock mass are all ranges, while the adjacent older rock bodies are basins.

\section{Discussion}

\subsection{Influence of Tectonism on Basin-range Pattern of Granite Masses}

As illustrated in the classical geomorphology theory, tectonic movement plays a decisive role in controlling the large-scale geomorphology on the earth (Summerfield. 1986). The multistage tectonic movements have also determined the large-scale basin-range pattern of Hunan Province. The magmatic activities in Hunan Province are mostly controlled by the post-collisional or the intracontinental post-orogenic extensional tectonic environment. The Mesozoic magmatic movements in this area also showed evident zonation, and the spatial distribution of the magmatic rocks exhibits the same zonal characteristics (Yang et al. 2012).

In general, there are always intense magma movements along an orogenic belt with the influences of the tensile activities of the faults along the belt and the delamination of mantle and lower crust (Wang et al. 1991). Controlled by the large-scale tectonic framework, some granite concentrated zones are formed along some mountain ranges, including Xuefeng Mountain, Luoxiao Mountain, and Nanling Mountain. Meanwhile, many granite mountains are formed, such as Wanyang mountain, Zhuguang mountain, Dadong mountain, Yuecheng mountain, Jiuyi mountain, miao'er mountain, Baima Mountain and Wangyun mountain. 
After the Caledonian magmatism, some other tectonic movements occurred successively, such as Yanshanian movement and Indosinian movement, and produced many large-scale tectonic systems. The earlier rock bodies may be affected by the later tectonic movement, resulting in some compressional uplifts and staggered faults, which controlled the basin-range evolution processes of some granite masses. For example, the XupuChengbu Fault in the east of the Xuefengshan tectonic belt experienced a strike-slip in the Yanshan Period, which cut off the Caledonian Baimashan rock mass, Indosinian Wawutang rock mass and Indosinian Wutuan rock mass in the north-south direction. For a specific rock mass, the uplifted part tends to develop into range, such as the Wutuan rock mass.

From the Early Cretaceous to the Paleocene, the tectonic evolution of Hunan Province turned be a new stage characterized with a series of deep-seated extension systems, which produced many horsts and grabens. During this process, some granite bodies were up-lifted and finally developed into ranges, of which Nanyue rock mass is the most representative example.

Since the Miocene Period, the Neotectonics movements have been influencing the surface morphology of most areas in Hunan Province. In this stage, the crustal uplifts in eastern, southern, western and north-western Hunan are obvious and continuous, while the Dongting Lake area in the northeast has been intermittent subsidence (Bo et al. 2011). The crustal uplift accelerated the denudation of overlying strata of granite rock masses and exposed some deep granite bodies to the surface (Bell 2016).

\subsection{Comparative Analysis of Resistance to Weathering \\ 4.2.1 Comparison of mineral compositions between granite rocks and their surrounding rocks}

According to the previous statistics, the surrounding rocks of the granite basins in Hunan Province are mainly slate, and of the granite ranges are mainly carbonate rocks. Hunan has the subtropical monsoon climate with relatively high temperature and large rainfall and chemical weathering is the dominant weathering type. The carbonate areas always present as basins just because of the higher solubility of calcite and dolomite than granite minerals (Pye 1986; Cui et al. 2007). It can also be proved that the difference of mineral contents between granite and slate determines the basin-range relationship between them.

The granites in Hunan Province are mainly monzonite, with less amount of granodiorite. The average mineral compositions of granitic bodies in different geological ages can be obtained based on statistical analysis of the mineral compositions of 394 granitic samples (Table 2).

Table 2 shows that, the average contents of K-feldspar, plagioclase, quartz and mica for 394 samples are $31.1 \%, 33.1 \%, 29.3 \%$ and $5.7 \%$ respectively, and the mineral contents of rock masses in different geological ages are obviously different. The average contents of plagioclase and biotite in the Silurian Period and Middle Triassic Period are significantly higher than the later geological ages, while the average contents of K-feldspar and quartz are lower than the later ages. Goldish and Carroll (Goldish 1938; Carroll 2012) summarized the mineral-stability series in weathering, namely quartz > muscovite $>$ K-feldspar > plagioclase $>$ biotite $>$ hornblende $>$ pyroxene $>$ olivine. According to this series, the rock bodies of the Silurian Period and the Middle Triassic Period is more likely to be weathered than the later rock bodies, that is the main reason why the younger rock bodies are more likely to develop into ranges in a composite rock mass.

Table 2

Average mineral content of granite in different periods in Hunan Province

\begin{tabular}{|lllllll|}
\hline Geological age & Number of samples & Quartz (\%) & Potash feldspar (\%) & Plagioclase (\%) & Biotite (\%) & Total (\%) \\
\hline Silurian & 67 & 26.4 & 24.1 & 39.5 & 7.9 & 97.9 \\
\hline Middle Triassic & 72 & 31.3 & 25.4 & 35.7 & 7.5 & 99.9 \\
\hline Late Triassic & 97 & 29.6 & 35.9 & 29.9 & 4.3 & 99.8 \\
\hline Middle Jurassic & 109 & 30.1 & 31.7 & 32.6 & 5.4 & 99.8 \\
\hline Late Jurassic & 49 & 29.2 & 38.4 & 27.9 & 3.6 & 99.1 \\
\hline Average & 79 & 29.3 & 31.1 & 33.1 & 5.7 & 99.3 \\
\hline
\end{tabular}

The slates in Hunan Province mainly formed in the Wuling Period and Caledonian Period under the influence of regional tectonic movements, which are distributed in the strata of the Proterozoic Lengjiaxi Group, the Proterozoic Banxi Group, the Nanhua Period and the Silurian Period (Zhang et al. 1987). Statistical results of the average mineral contents of different types of slate were given in Table 3 . Table 3 shows that, sericite and quartz are dominate minerals for the main types of slate. Except for carbonaceous slate, the content of sericite and quartz of other types of slate accounts for more than $80 \%$ at least.

As a fine-grained type of muscovite, sericite is the product of low and medium temperature alterations or shallow metamorphisms, and has stable chemical properties (Yang et al. 2006). Experiencing more tectonic movements accounts for the higher fracture rate of the slates in Hunan Province which formed ahead of Silurian, whereas their mineral compositions are more resistant to weathering. 
Table 3

Average mineral contents of different types of slate in Hunan Province

\begin{tabular}{|lllllll|}
\hline Lithology & \multicolumn{7}{l|}{ Average mineral composition (\%) } & & \\
\cline { 2 - 7 } & Sericite & Quartz & Feldspar & Biotite & Muscovite & Organic matter \\
\hline Sericite slate & $88 \sim 95$ & $5 \sim 10$ & $/$ & $/$ & $/$ & $/$ \\
\hline Silty slate & $70 \sim 74$ & $25 \sim 35$ & $1 \sim 5$ & $/$ & $/$ & $/$ \\
\hline Gravelly sandy slate & $48 \sim 54$ & 35 & 3 & $1 \sim 2$ & $1 \sim 5$ & $/$ \\
\hline Carbonaceous slate & 15 & $3 \sim 10$ & $/$ & $/$ & $/$ & $37 \sim 45$ \\
\hline Siliceous slate & $25 \sim 30$ & $70-75$ & $/$ & $/$ & $/$ & $/$ \\
\hline
\end{tabular}

\subsubsection{Comparative analysis of soil infiltration conditions between granite and slate}

In those areas dominated by chemical weathering, rainfall infiltration plays an essential role in the weathering process. The more rainfall infiltrates into the soil, the more opportunities for water-rock interaction and accordingly the faster the weathering.

Determined by the unique characteristics of mineral compositions, weathered soil of granite is characterized by high sand and gravel content, loose soil, and large permeability (Nesse 2012). According to the statistical result completed by Zheng and Bennett (2002), the permeability coefficient of weathered granite soils is generally in the range of $0.25 \sim 2.50 \mathrm{~m} / \mathrm{d}$.

Slate is mainly formed by light metamorphism of mudstone, argillaceous siltstone or tuff, and the weathering products on its surface are mostly clay or loam. The permeability coefficient of this soil is generally between 0.001 and $0.01 \mathrm{~m} / \mathrm{d}$ (Zhang et al. 2009), which is much lower than that of granite weathered soil. As a result, it may be argued that the rainfall infiltration in granite area is greater than that in slate area, which is another important reason why the weathering rate of granite is larger than slate in hot and humid climate.

\subsubsection{Comparative analysis of material flux analysis}

For a closed basin, material flux of the export can roughly reflect the average weathering rate of the basin if without considering the impact of human activities (Gurumurthy et al. 2012). The average sediment transport modulus and chemical flux modulus of each catchment area determined by related hydrological station were calculated based on the collected sediment and water quality data and the results were showed in Table 4 and Table 5.

It can be concluded from Table 4 and Table 5, that the sediment transport modulus and chemical flux modulus of all basins are closely related to the dominant lithology. Table 4 shows that, the basins dominated by carbonate rock and slate have the smallest sediment modulus with the maximum value of $101.1 \times 103 \mathrm{~kg} / \mathrm{km}^{2} \cdot \mathrm{a}$, and the clastic sedimentary rock basin is in the middle, while the two granites basin show the highest sediment transport modulus, of which the Oushui basin is $219.9 \times 103 \mathrm{~kg} / \mathrm{km}^{2} \cdot \mathrm{a}$ and the Wushui basin even reach up to $655.3 \times 103 \mathrm{~kg} / \mathrm{km}^{2} \cdot \mathrm{a}$. In 2007, Xiao et al (2007) pointed out that, there are three small basins with the sediment transport modulus over $200.0 \times 103 \mathrm{~kg} / \mathrm{km}^{2} \cdot \mathrm{a}$ in Hunan Province, including the Oushui Basin, Wushui Basin, and Wujiang Basin, which are all granite basins.

Table 5 shows the characteristics of hydrochemical flux modulus of different basins, which are quite different from those of sediment transport flux modulus. The carbonate basins have the highest hydrochemical flux modulus, which is generally more than $150 \mathrm{~kg} / \mathrm{km}^{2} \cdot \mathrm{a}$. The average hydrochemical flux modulus of clastic rock areas is only lower than that of carbonate rock basins. Different from the huge difference in sediment transport flux, both the slate basin and the granite basin present the characteristics of low hydrochemical flux. The average hydrochemical flux modulus of the 4 basins dominated by slate rock in the Table 5 is about $57.4 \times 103 \mathrm{~kg} / \mathrm{km}^{2}$.a, and the maximum value is only $74.6 \times 103 \mathrm{~kg} / \mathrm{km}^{2} \cdot \mathrm{a}$. Contrary to the highest value of the sediment transport modulus, the granite basin is characterized by the lowest hydrochemical flux modulus with an average value of about $45.0 \times 103 / \mathrm{km}^{2} \cdot \mathrm{a}$, and the maximum value is only $53.9 \times 103 / \mathrm{km}^{2} \cdot \mathrm{a}$. In 1999 , Chen et al carried out a comparative study on the hydrochemical flux modulus of different lithologic areas in the Pearl River Basin adjacent to Hunan Province (Chen et al. 1999). They proposed a hydrochemical flux sequence of carbonate rock > clastic rock > slate rock $\approx$ granite rock for different geological background basins. According their statistics, the average hydrochemical flux modulus of the 4 types of basins are $269.8 \times 103 \mathrm{~kg} / \mathrm{km}^{2} \cdot \mathrm{a}, 151.5 \times 103 \mathrm{~kg} / \mathrm{km}^{2} \cdot \mathrm{a}, 54.3 \times 103 \mathrm{~kg} / \mathrm{km}^{2} \cdot \mathrm{a}$ and $71.1 \times 103 \mathrm{~kg} / \mathrm{km}^{2} \cdot \mathrm{a}$ respectively, which are well consistent with the results of this paper.

Based on the above analysis of the sediment transport and chemical flux modulus, the overall material flux without considering water of the basins can be roughly compared. In the slate basin, the sediment transport modulus and chemical flux modulus are both small, that means the basin's weathering is also at a low level. Although granite basins present low hydrochemical flux modulus, the total material flux modulus are much higher than slate basins for its highest sediment transport modulus. Controlled by the characteristics of easy-dissolved, the hydrochemical flux modulus of carbonate rock basin is much higher than that of other types of basins, which makes its total material flux the highest, though it has lower sediment transport flux modulus. 
Table 4

Average annual sediment transport modulus of typical stations

\begin{tabular}{|llll|}
\hline Station & River & Dominate lithology of the basin & Average sediment transport modulus \\
\hline Laobutou & & & $10^{3} \mathrm{~kg} / \mathrm{km}^{2} . \mathrm{a}$ \\
\hline Hengyang & Xiangjiang & Carbonate rocks & 78.8 \\
\hline Xiangtan & Xiangjiang & Multi-lithology & 88.8 \\
\hline Daoxian & Xiaoshui & Curbonate rocks & 105.5 \\
\hline Zhaiqian & Oushui & Granite & 101.1 \\
\hline Shenshantou & Zhenshui & Multi-lithology & 219.9 \\
\hline Jingtoujiang & Wushui & Granite & 107.3 \\
\hline Ganxi & Mishui & Multi-lithology & 655.3 \\
\hline Shuangjiangkou & Liuyanghe & Slate & 117 \\
\hline Daxitan & Lushui & Clastic rock & 78.8 \\
\hline
\end{tabular}


Table 5

Average annual hydrochemical flux modulus of typical stations

\begin{tabular}{|c|c|c|c|}
\hline Station & River & Main lithology of the basin & Average sediment transport modulus \\
\hline & & & $10^{3} \mathrm{~kg} / \mathrm{km}^{2} \cdot \mathrm{a}$ \\
\hline Daoxian & Xiaoshui & Carbonate rock and slate & 155.3 \\
\hline Laobutou & Xiangshui & Carbonate rock and slate & 156.2 \\
\hline Loudi & Lianshui & Carbonate rock & 307.1 \\
\hline Lianyuan & Lianshui & Carbonate rock & 343.9 \\
\hline Shuangfeng & Meishui & Carbonate rock & 209 \\
\hline Shuangjiangkou & Liuyang & Slate & 47 \\
\hline Daxitan & Lushui & Clastic rock & 112.2 \\
\hline Shenshantou & Zhenshui & Clastic rock and slate & 64.8 \\
\hline Loulingqiao & Jinjing & Slate and granite & $74.6^{*}$ \\
\hline Tongtang & Lushui & Clastic rock & $166.6^{*}$ \\
\hline Shimenkan & Zhenshui & Clastic rock and slate & $70.5^{*}$ \\
\hline Guiyang & Xiangjiang & Carbonate rock & $147.6^{*}$ \\
\hline Mazaidu & Shiqihe & Carbonate rock & $154.2^{*}$ \\
\hline Jiangyong & Yongming & Slate and limestone & $60.7^{\star}$ \\
\hline Jiangyong & Tuojiang & Slate and granite & $47.4^{*}$ \\
\hline Jiahe & Zhongshui & Carbonate rock and granite & $128^{\star}$ \\
\hline Ningyuan & Lengshuihe & Carbonate rock and slate & $124.9^{*}$ \\
\hline Xintian & Xintian & Carbonate rock and slate & $104.5^{*}$ \\
\hline Xihe & Xishui & Carbonate rocks & $199.1^{*}$ \\
\hline Chenzhou & Chenjiang & Granite and carbonate rock & $49.2^{*}$ \\
\hline Wenming & Wenming & Granite and sandstone & $41.3^{*}$ \\
\hline Zhaiqian & Oushui & Granite & $53.9^{*}$ \\
\hline Wulipai & Mianshui & Granite & $35.2^{*}$ \\
\hline Anren & Yongle & Clastic rock and granite & $56.7^{*}$ \\
\hline
\end{tabular}

\section{Conclusions}

In this paper, a statistical study on the basin-range relations between the granites and their surrounding rocks in Hunan Province was carried out, and the formation mechanisms were analyzed from two main aspects of tectonic evolution and the differences of anti-weathering between the granites and their surrounding rocks. The result was verified by the analysis of material flux.

Among the 44 granitoids in Hunan Province, 28 are basins, 14 are ranges, and only 2 cannot be directly classified. According to the statistical results of their surrounding rocks, the basin-range properties of granite bodies are closely related to the lithology of surrounding rocks. Among the 28 granite basins, 24 are surrounded by slate, 3 by sandstone, and only 1 by glutenite, while 11 of 14 ranges are surrounded by carbonate rocks.

Tectonic movements determined the large-scale basin-range pattern of granites in Hunan Province. Controlled by the large-scale tectonic framework, some granite concentrated zones are formed along some mountain ranges, including Xufeng Mountain, Luoxiao Mountain, and Nanling Mountain. The earlier rock bodies may be affected by the later tectonic movement, resulting in some compressional uplifts and staggered faults, which controlled the basin-range evolution processes of some granite masses, such as the Wutuan Rock Mass and the Nanyue Rock Mass.

The difference of resistance to weathering between granite and surrounding rock is a controlling factor for the development of granite basin or range. Because of the high solubility of carbonate minerals, the weathering speed in carbonate area is the fastest, so the granite rock areas always present as 
ranges when their surrounding rocks are carbonate rocks. The minerals of slate rocks in Hunan Province have higher resistance to weathering than granite minerals. In addition, the surface soil in granite area is more conducive to rainfall infiltration than slate area, which means that the granite has more chances of weathering. Controlled by the above two factors, the weathering rate of the granite areas in Hunan Province is higher than that of the slate areas, so that when the surrounding rocks are slate rock, the granite areas always present as basins. The differences of resistance to weathering between different types of rock basins are verified by the analysis results of sediment transport modulus and hydrochemical modulus.

\section{Declarations}

\section{ACKNOWLEDGMENTS}

The authors thank the anonymous reviewers for their helpful comments.

Funding: This work was supported by National Natural Science Youth Fund Project (41602264); Hunan Natural Science Youth Fund Project (2020JJ5572); "Double first class" scientific research international cooperation development project of Changsha University of Technology (2019IC08)

Conflicts of interest/Competing interests: All authors certify that they have no affiliations with or involvement in any organization or entity with any financial interest or non-financial interest in the subject matter or materials discussed in this manuscript.

\section{References}

1. Andre M, Piotr M (2006) Granite Landscapes of the World. Oxford University Press, Massachusetts

2. Bai DY, Huang JZ, Liu YR et al (2005) Framework of Mesozoic tectonic evolution in southeastern Hunan and the Hunan-Guangdong-Jiangxi border area. Geology in China 05(04):33-46

3. Bai DY, Huang JZ, Ma TQ, Wang XH et al (2006) Geology and geochemistry of the Silurian Penggongmiao granitic pluton in the southeastern Hunan Province and its implication for tectonic setting. Geoscience 06(01):130-140

4. Bai DY, Huang JH, Li JD et al (2007) Multiple geological elements constrainton the Mesozoic tectonic evolution of south China: apocalypse of the Mesozoic geological evolution in southeastern Hunan and the Hunan-Guangdong-Jiangxi border area. Geotectonic aet Metallogenia 07(01):1-13

5. Bai DY, Wang XH, Li CA et al (2011) Characteristics of quaternary tectonic evolution in Dongting basin. Geological Review 57(02), 261-276

6. Bell FG (2016) Fundamentals of Engineering Geology, University of Baghdad-Iraq, Baghdad

7. Carroll D (2012) Rock Weathering. Springer Science \& Business Media, NY

8. Chen JS, He DW (1999) Chemical characteristics and genesis of major ions in the Pearl River basin. Acta Scientiarum Naturalium Universitatis Pekinensis 35(06):786-793

9. Cui ZJ, Yang JQ, Chen YX et al (2007) The type and evolution of the granite landforms in China. Acta Geographica Sinica 62(07), 675-689

10. Goldich SS (1938) A study in rock-weathering. The Journal of Geology 46(01), 17-58

11. Gurumurthy GP, Balakrishna K, Riotte J et al (2012) Controls on intense silicate weathering in a tropical river, southwestern India. Chemical Geology s300-301:61-69

12. Li BY, Pan BT, Cheng WM, Han JQ, Qi DL, Zhu C (2013) Research on geomorphological regionalization of China. Acta Geographica Sinica 68:291306

13. Li GH (2008) Discussion on genesis of the Zhangzhou basin-a differential erosion basin rather than a fault-depressed basin. GEOLOGICA L REVIEW 54:199-206

14. Liu KL, Li ZL, Xu WG, Ye HM, Zhao XL (2016) The spatial-temporal distributions and migrations of Mesozoic magmaism in south China and subduction process of the Paleo-Pacific Plate. Bulletin of Mineralogy, Petrology and Geochemistry 35(06):1141-1155

15. Shu LS (2012) An analysis of principal features of tectonic evolution in South China Block. Geological Bulletin of China, 31(07):1035-1053

16. Summerfield MA (1986) Tectonic geomorphology: macroscale perspectives. Progress in Physical Geography: Earth and Environment 10(02):227238.

17. Sun ZM, Cao Y, Li HB (2019) A review of paleomagnetic study of the formation and evolution of the Tibetan Plateau. Acta Geoscientica Sinica 40(01):17-36

18. Nesse WD (2012) Introduction to Mineralogy. Oxford University Press, Massachusetts

19. Pi JG, Zhang GL, Liang X (2001) Preliminary research on sedimentary environment evolution in Dongting basin in the Quaternary period. Geological Science and Technology Information, 20(02):6-10

20. Powell CMA, Conaghan PJ (1973) Plate tectonics and the Himalayas. Earth and Planetary Science Letters 20:1-12

21. Pye K (1986) Mineralogical and textural controls on the weathering of granitoid rocks. Catena 13:47-57

22. Twidale CR (1982) Granite Landforms. Elsevier Scientific Publishing Company, Amsterdam

23. Twidale CR, Romani JRV (2005) Landforms and Geology of Granite Terrains. Taylor \& Francis, London 
24. Wang CL (1991) Study on Neotectonics in Hunan Province. Journal of Hunan University of science and Technology (Social Science Edition) 12:61-68

25. Wang QH, Xu WL (2003) The deep process of formation and evolution of Songliao Baisn-Mesozoic volcanic rock probe. Journal of Jilin University (Earth Science Edition) 33(01):37-42

26. Xiao ZH, Ye ZG (2007) Analysis of sediment characteristics of main rivers in Hunan Province. Pearl River 1:17-19

27. Yang CH, Mao HJ, Wang XC (2006) Study on variation of microstructure and mechanical properties of water-weakening slates. Rock and Soil Mechanics 27(12):2090-2098

28. Yang JC, Li YL (2012) Principle of Geomorphology. Beijing: Peking University Press, Beijing

29. Yang X, Wang YD, Liu XW (2012) Characteristic and dynamical mechanism of post-collision extensional basins. Geological Review 58(03):444450. (in Chinese with English abstract)

30. Zeng ZX (1960) Rock Topography. Geological Publishing House, Beijing

31. Zhang YY (2009) Eroding soil types and their management counter measures of granite regions in Guangdong Province, China. Journal of Mountain Science 27(01):51-55

32. Zhang LC, Zhao GJ, Dong WJ et al (1987) Geochemical characteristics of the Xiang Jiang river system. Acta Geographica Sinica 42(03):243-251

33. Zheng C, Bennett GD (2002) Applied contaminant transport modeling. Wiley-Inter science, New York

34. Zhou ZY, Liao ZT (2005) The model for the subduction and collision of the Indian plate with the Eurasian plate and its im-plications for the tectonic evolution of the Qinghai-Xizang Plateau. Sedimentary Geology and Tethyan Geology 25:27-32

Figures

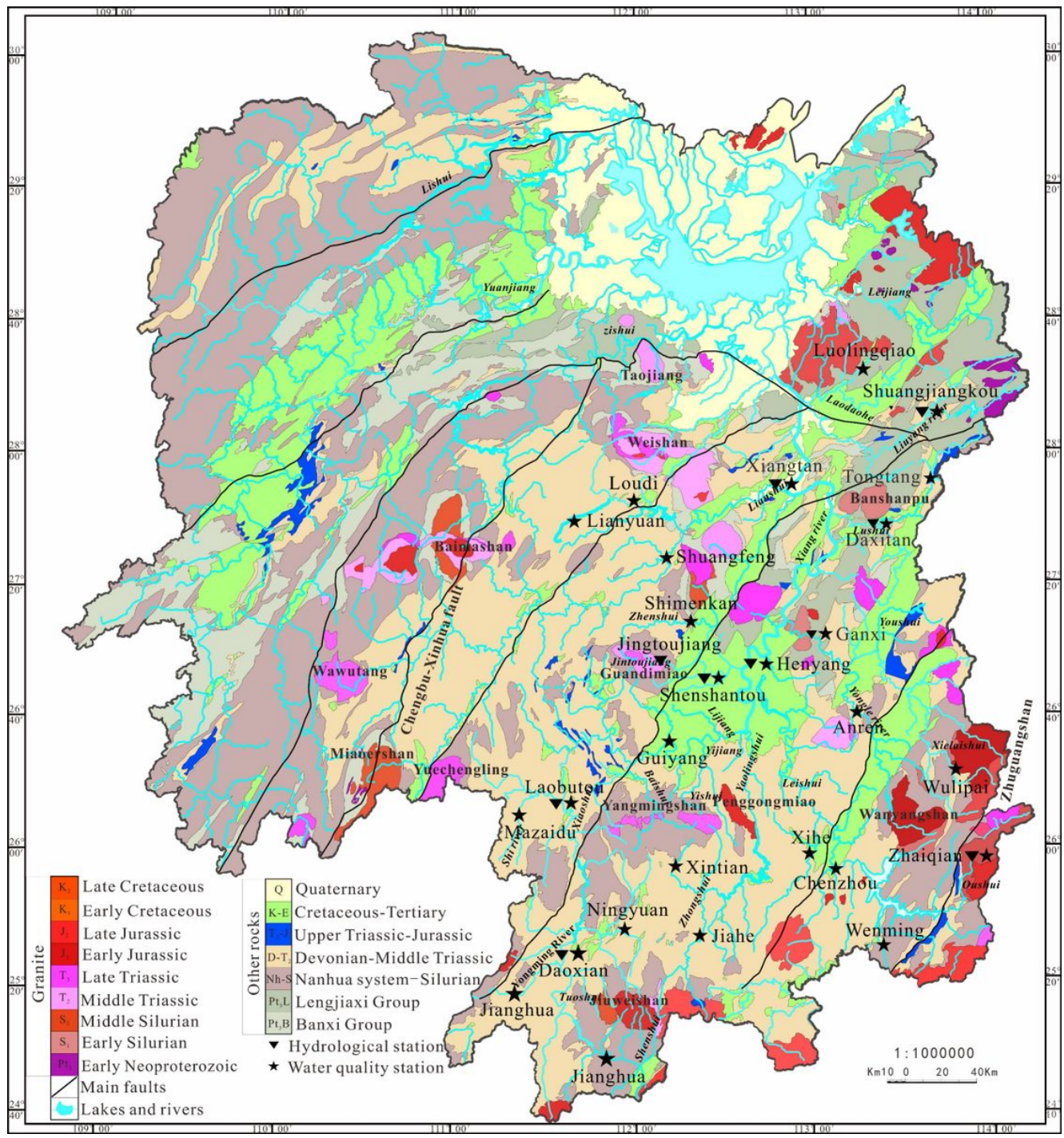

\section{Figure 1}

Hunan geological map and data sources points. 


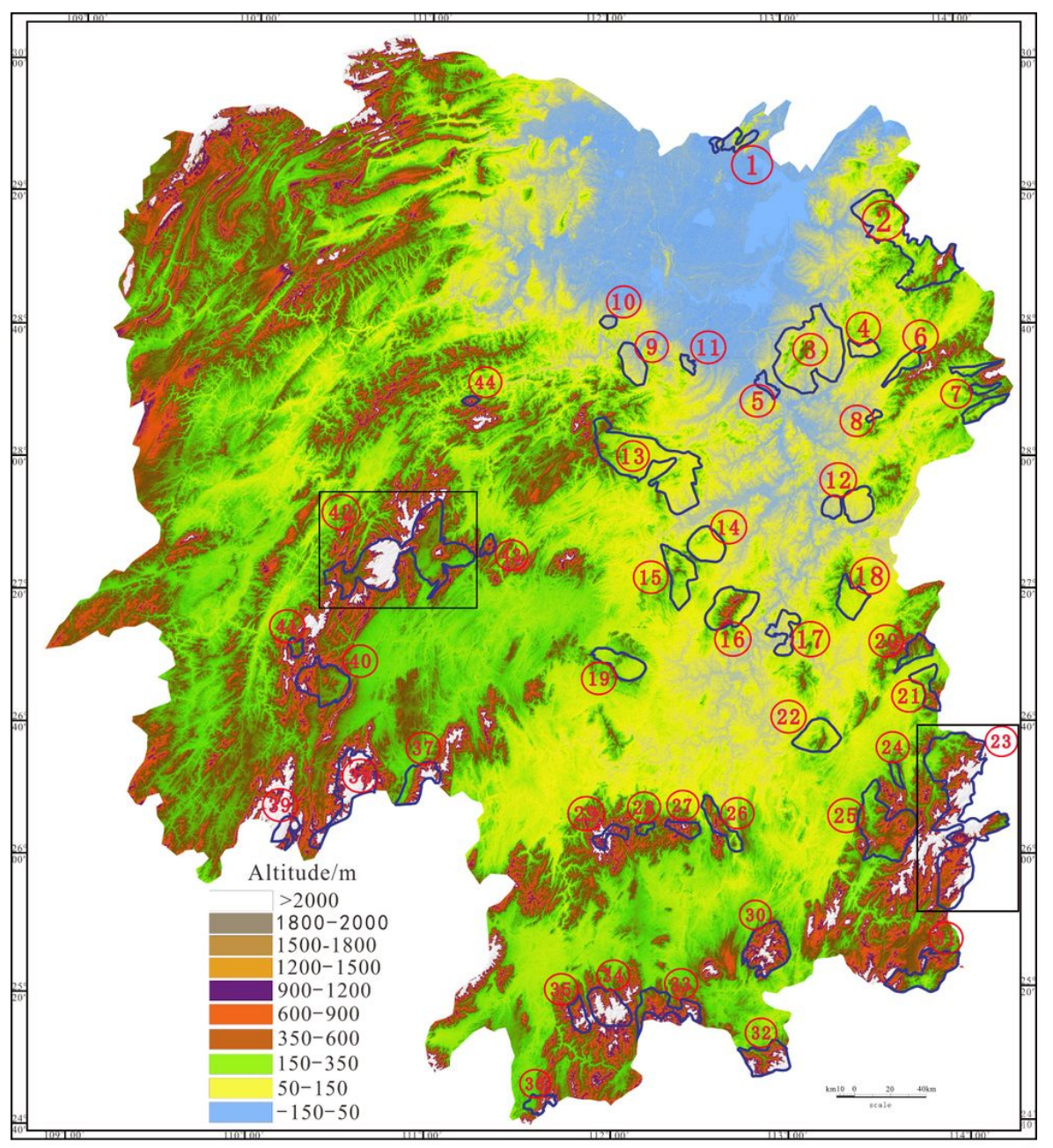

\section{Figure 2}

Nested map of granite and topography in Hunan Province.

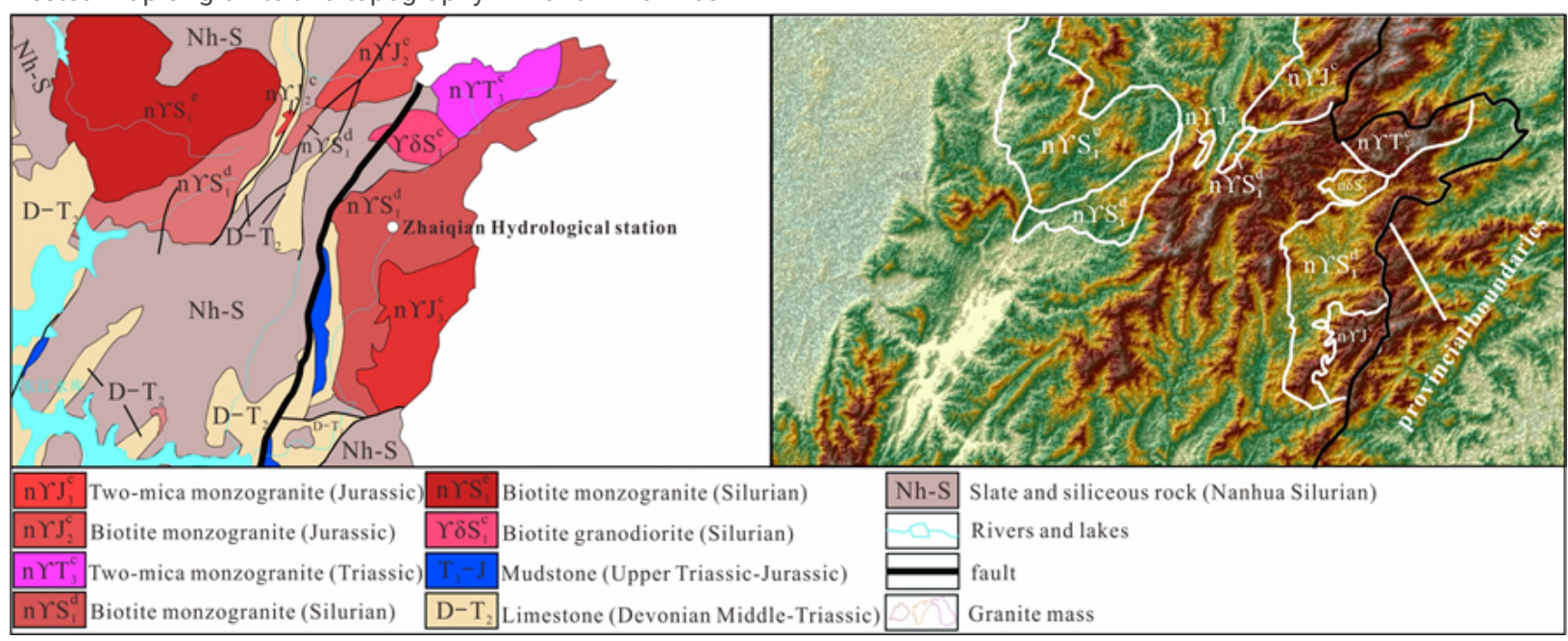

Figure 3

Basin-range framework of the North-Zhuguangshan rock mass. 


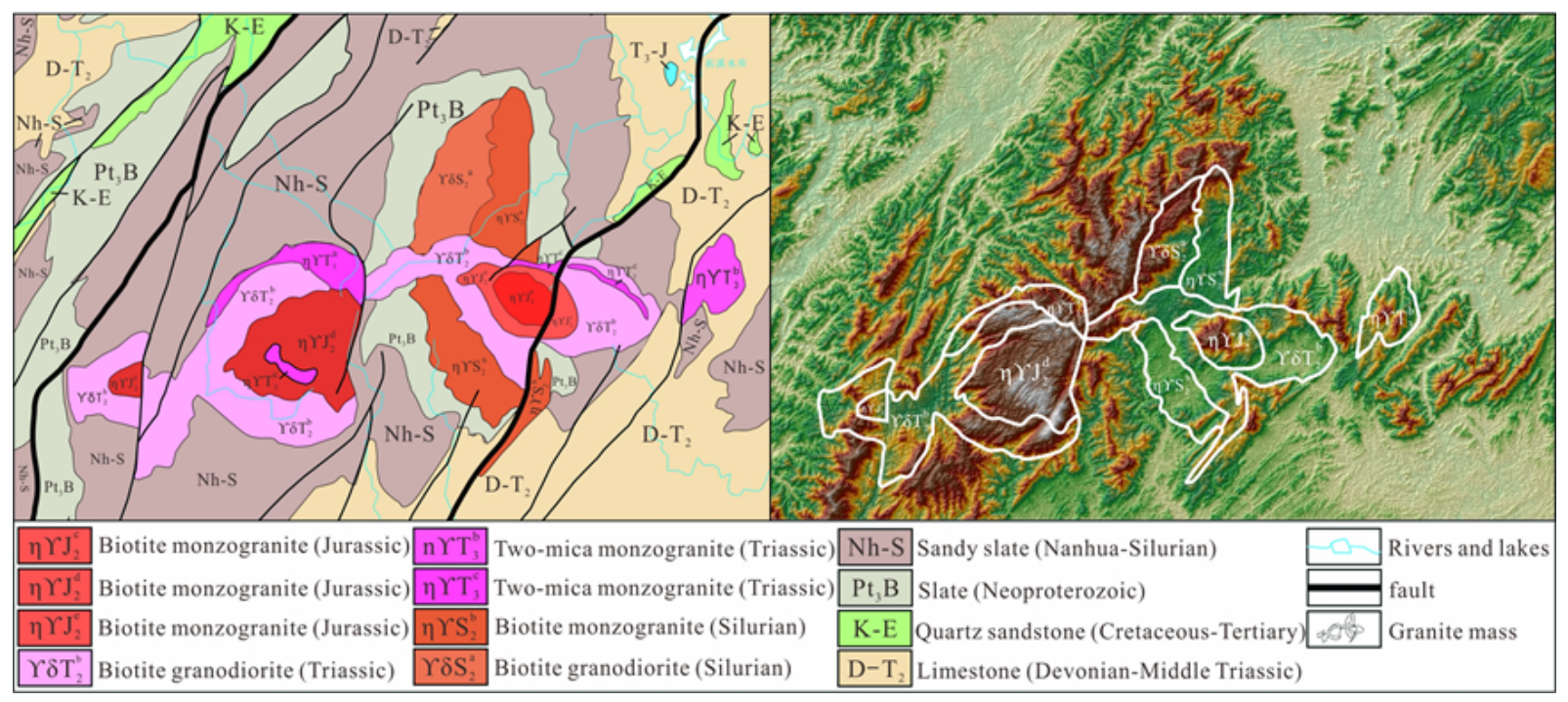

\section{Figure 4}

Basin-range framework of the Baimasi rock mass. 